Copyright $(1998$ The Johns Hopkins University Press. All rights reserved.

Arethusa 31.1 (1998) 75-97

\title{
Self and Community in the Younger Pliny
}

\section{Andrew M. Riggsby}

Pliny the Younger described himself as an imitation, if a somewhat pale one, of Cicero (4.8.4-5, 9.2.2-3). 1 In a recent paper examining this connection, I argued that its value for Pliny lay in the identification of both men as orators and the further identification of the orator as an "engaged public figure." ? In this paper, I want to nuance that claim by giving further consideration to the connection between "engaged" and "public." Examination of this notion involves consideration of the interaction of individuals with a community and the way this interaction is framed in ethical terms. This, in turn, leads to the question of the precise nature of the individual/community distinction. A reading of Pliny's letters against the texts of some of his near contemporaries reveals significant differences in their respective theories of the self and its interaction with the world. In particular, Pliny can be shown (contrary to some recent accounts) to employ for the most part a remarkably conservative notion of the relationship between individual and community.

In letter 5.3, Pliny defends his production of light verse not only with exempla of senators and emperors (including Cicero) who did the same (5.3.5), but also of Vergil, Nepos, Accius, and Ennius, who are included on the strength of their sanctitas morum (5.3.6). $\underline{3}$ The Roman elite had always conflated their social standing and political authority with moral [End Page 75] superiority to some degree. It would be but a short step for Pliny to construct, if only locally, a hierarchy of authority based purely on moral grounds; he makes only a token apology for the possible innovation. Compare Pliny's teacher Quintilian, who enthusiastically adopts Cato's definition of the orator as a uir bonus dicendi peritus, "a good man, skilled in speaking" (1.pr.9; 2.15.33-34, 16.11, 17.31; 12.1.1, 3). This definition and Quintilian's entire discussion of the perfect orator (12.1) focus on an ethical interpretation of the role of the orator, quite likely in response to the role of delatores in unpopular prosecutions. 4 To Pliny'spriuata exempla we might also compare the entire collection of Valerius Maximus. Bloomer $1992.19,147-229$ notes a procedure of "dehistoricization" that goes on in the composition of his exempla. The details of Republican power politics are elided so as to better fit the stories to the moral categories that structure 
Valerius' work. We ask, then, whether Pliny's view of the orator has taken part in this moralization. If so, does that make the orator's significance more "private" or is Pliny merely extending the traditional tendency to conflate moral and social order?

Pliny's most extensive discussion of the function of the orator is 6.29. He starts (§§1-2) by accepting the three reasons advanced by one Thrasea for accepting legal cases: $\underline{5}$ friendship, charity to those without other options, and the importance of precedent-setting (ad exemplum pertinentes) cases. He then adds a fourth category of his own: glorious and notable cases (§3). Friendship is certainly an ethical issue; charity could be considered under this head, though Pliny also recommends it because it will improve the orator's reputation (§2). Similarly, famous cases will improve the orator's visibility. But why the cases ad exemplum pertinentes? Because their outcome actually matters (§2): quia plurimum referret, bonum an malum induceretur, "because it matters much whether good or ill results." [End Page 76] At the end of the letter, Pliny lists several cases he has undertaken under this head (§§8-11). They are all criminal prosecutions and defenses (mostly repetundae), public cases the likes of which had made Cicero's reputation. Thus the orator not only may, but must, take action which is "public" in the strongest sense: it is not only visible, but consequential for the community. In some sense, this too may be regarded as a demand on the orator's character, but the orator is nonetheless judged ultimately by concrete effects he will have on those around him.

This last distinction is crucial for understanding the place of the orator in Pliny's scheme. Even when he discusses taking these political cases, Pliny uses the same ethical language that he used of less obviously public activity like writing poetry (deceat, 6.29.11; cf. 5.3.5). We may well accept that Pliny represents the roles of orator and senator as, in general, ethical roles. Yet his persistent references to the engagement and effectiveness of the orator should remind us to be careful about what this might have meant in a Roman context. It does not imply a focus on an "inner" self that it might for a modern American (or even for someone like Seneca the Younger). $\underline{6}$ Pliny also had available a more conservative view in which virtue is constructed under (perhaps even by) the gaze of the community. $\underline{?}$

Before proceeding further with the analysis of Pliny, I would like to introduce a theoretical distinction proposed by Michael Carrithers. Carrithers (drawing his terminology from Marcel Mauss) distinguishes "personnetheories" and "moi-theories" of the individual. ${ }^{8}$ A personne-theory is socially oriented; it is a "conception of the individual human being as a member of a (1) significant and (2) ordered collectivity" (Carrithers 1985.235). [End Page 77] By contrast, moi-theories are both more and less individualizing; they offer a "conception of (1) the physical and mental individuality of human beings within (2) a natural or spiritual cosmos, and (3) interacting with each 
other as moral agents" (Carrithers 1985.236). The second clause produces a universalizing tendency, while the last gives moi-theories a certain individualistic flavor. That is, on the one hand, "natural" and other universal standards are conducive to understanding individuals serially and separately. On the other, a social standard requires considering communities holistically. For expository purposes, Carrithers restricts himself to the description of explicit, well-articulated theories rather than "folk" theories or pervasive metaphorical structures, but there is no need to so limit ourselves here. Furthermore, I am not interested in discussing such questions as whether all societies exhibit both (or even either) types of theory or whether all theories of the individual can usefully be described in one or the other set of terms. 9 I suggest only that the distinction will be useful in characterizing Pliny's understanding of the "public" and bringing out his differences with a number of contemporary thinkers. Finally, it is important to point out that it is possible (perhaps even normal) for a single person to hold theories of both sorts. The question in what follows will be how Pliny and others made different use of the available theories at roughly the same time.

In the terms just introduced, Roman traditions of evaluation (which we will see Pliny tends to follow) constitute a normative theory of the personne: these traditions emphasize evaluation of individuals by the community and in terms of their effects on that community. 10 Obligations[End Page 78] are both based on the social role of the individual and defined in terms of the interaction of that role with other roles and with the society as a whole. Traditional aristocratic thinking may well have included some sort of moiidea, but it was the personne around which their values were organized. As the epitaph of L. Cornelius Scipio (cos. 259) says (CIL I $\stackrel{2}{2} 9.1-2,5-6)$ :

Honc oino ploirume consentiont R[omai]

Duonoro optumo fuise uiro ...

Hec cepit Corsica Aleriaque urbe.

Dedet Tempestatebus aide mereto[d]. 11

Most at Rome agree that this one

Was the best man of all the good...

He took Corsica and the city of Aleria.

He rightly gave a temple to the Storms.

This inscription illustrates both the standard of community evaluation and a concomitant emphasis on public achievement. The aristocrat's duty is not so much to be good, as to do good. $\underline{12}$ Nor was this mode of evaluation [End Page 79] restricted to certain spheres; the Romans did not in this sense distinguish the domestic from the public. Dionysius remarked with surprise that the censors' gaze at Rome did not (at least in principle) stop at the door of a man's house, as would be expected of state surveillance in Greece (AR 20.13.3). 13 The language of political invective had always been intensely domestic: descent, sexual perversions, luxury, personal 
appearance. 14 Though not logically entailed by the principle that moral value is assigned by collective judgment, this situation illustrates the reach of that principle. If domestic life is to be afforded any moral value at all, it inevitably becomes a public matter. Conventional Roman moralizing takes place under a socially-oriented theory, apersonne-oriented one.

To demonstrate Pliny's employment of the same kind of social standards outside of oratory we may look to two of Pliny's letters that deal with his poetry $(4.14,5.3)$. These letters will show that even "private" (in the sense of domestic) actions are given value by their public reception. Ep. 4.14 is a cover letter for a collection of light verse; 5.3 discusses rumored reactions to this or similar verse. In both letters, Pliny spends most of his time defending the propriety of writing such poetry. This move has understandably been described as "a fervent defense of his private lyrical self," but it is a defense based on public, collectivist grounds. At 4.14.10 Pliny asks for his correspondent's honest judgment in a curious way: a simplicitate tua peto, quod de libello meo dicturus es alii, mihi dicas, "I call on your frankness in asking that you tell me what you are going to tell another about my book." He wants to know the evaluations of himself that will be in circulation. Note also that the indicative es shows that he assumes that this circulation will naturally take place. $\frac{15}{15}$ We may compare this to the opening of the other letter (5.3.1): Cum plurima officia tua mihi grata et iucunda sunt, tum uel maxime quod me celandum non putasti, fuisse apud te de uersiculis meis multum copiosumque sermonem . . [reported criticism follows]. "Your many services to me are pleasing and obliging, and especially the fact that you thought that it ought not be hid from me that [End Page 80] there was much discussion about my verses at your house." In the following section, Pliny defiantly asserts his indulgence in this and other forms of light entertainment, finally concluding: aliquando praeterea rideo, iocor, ludo, utque omnia innoxiae remissionis genera breuiter amplectar, homo sum, "Sometimes I laugh, I jest, I play, and, to briefly encompass all forms of harmless relaxation, I am human." This appears to appeal to a different standard: a moi-theory under which, apparently, an individual may consult a generalized "human nature" on his own behalf rather than deferring to a community audience.

But in the immediately following words, he returns to a socially oriented standard (5.3.3): Nec uero moleste fero hanc esse de moribus mei existimationem, ut qui nesciunt talia doctissimos grauissimos sanctissimos homines scriptitasse, me scribere mirentur, "Nor do I take this judgment of my character hard; consequently those who do not know that the gravest, most solemn, and most learned men have written such things, wonder that I write them." 16 On this follows the long list of poet/statesman exempla cited above, including Cicero, Calvus, Pollio, Seneca, Augustus, and Nerva (5.3.5). Now, Habinek MS.42-48 has pointed out that the Roman use of exempla can be conceived of as retrojection of the process 
of existimatio into the (ideologically privileged) past; exempla are understood to show what the ancestors (maiores) approved or disapproved of. 17 This is precisely what is happening in this passage. Pliny, in defense against the negative evaluation (§3: existimationem) of his contemporaries, does not for long reject their authority in favor of a completely different kind of authority (i.e., essential human nature). Rather he appeals to a more weighty (doctissimos, grauissimos, sanctissimos) evaluating audience in the form of Cicero, Calvus, Asinius Pollio, et al.

After reviewing his various classes of exempla (republican senators, emperors, and virtuous poets), Pliny admits that he does not know whether they gave public recitations (5.3.7). That he himself does so is, he says, a sign of his greater modesty (\$7): sed illi iudicio suo poterant esse contenti, mihi modestior constantia est quam ut satis absolutum putem, quod a me probetur, "They could be content with their own judgment; I am [End Page 81] not so rash as to think that what I approve of is polished enough." $\mathrm{He}$ expands on this theme for the rest of the letter, finally concluding (§11): Atque haec ita disputo quasi populum in auditorium, non in cubiculum amicos aduocarim, "I discuss these things as if I have called the people into an auditorium, not friends into my chamber." $\underline{18}$ Thus Pliny claims ultimately to submit his "private" poetry to the same general public scrutiny as his oratory. This last remark of Pliny's may also suggest an interpretation of the fact that letter 4.14 asks for the recipient's judgment of the enclosed poems $(\S \S 6-8,10)$. On the one hand, the friend could be like Seneca's Lucilius--a practical check on one's skill and honesty in approaching some absolute goal. 19 On the other hand, a friend might be asked to serve as a representative of the judgment of the community at large. That Pliny asks his addressee to give him the same evaluation he gives others (4.14.10, quoted above) supports the latter interpretation. Pliny's later (5.3.11) description of his recital audience as quasi populum in auditori[o] confirms this view.

These letters have a direct bearing on issues already raised in this paper and in Riggsby 1995, but they are also of interest because of the somewhat different use to which Eleanor Leach has put them in her innovative discussion of "public" and "private" in Pliny's letters and in contemporary portrait sculpture. In this article (1990.20, 32, 38), Leach observes that the topic may profitably be studied with reference to Foucault's comments on the "individualism" or "turn inward" or "turn to the self" that is often taken to characterize the early centuries A.D. Foucault $1986.42-43$ points out that several, quite distinct, phenomena could be understood to fall under these rubrics: (1) the valorization and autonomy of the individual vis-à-vis the group, (2) the valorization of domestic life, and (3) an increase in "the intensity of the relations to self, that is, of the forms in which one is called upon to take oneself as an object of knowledge and a field of action, so as to transform, correct, and purify oneself, and find salvation ... . a 'cultivation 
of the self,' wherein the relations of oneself to oneself were intensified and valorized." In short, Leach and Foucault locate in Pliny and his contemporaries a new ethics which, in the terms adopted [End Page 82] here, constitutes a moi-theory. It emphasizes individuals interacting as such with each other and with themselves. Furthermore, the background for most of these theories is an organized (whether by reason or nature or both) cosmos.

Pliny clearly gives short shrift to the considerations of the first sort, the valorization and autonomy of the individual vis-à-vis the group. As we have already discussed, the individual (for Pliny) is to act for the benefit of the community, and his correctness is defined by the collective opinion of that community. We might also note in this connection the frequent qualifications Pliny makes to expressions of rejoicing, e.g., nec priuatim magis quam publice, "no more myself than as a member of the community" (5.14.6; cf. 2.7.6, 4.16.1, 5.11.2, 6.11.3, 10.1.2, 10.86b.1). Pliny appears anxious about expressing joy purely on his own behalf or on his own judgment (or perhaps either). Having isolated Pliny from this aspect of the "turn to the self," we might reasonably ask whether he allows himself to be guided by a moioriented theory in other respects.

It seems to me that Pliny does not participate in a significant, new valorization of the private or domestic. Leach 1990.31-35 discusses a number of cases in Pliny's letters where he seems to privilege private life (both his own and that of others), particularly as a check on the evaluation of more public behavior. This conception of the private is said to derive from the frequent, coerced discrepancy between public and private actions under Domitian, and to have led to Pliny's aggressive presentation of his private self under the more congenial reign of Trajan. But, as noted above, the domestic had for the Romans never been "private" in the modern sense. Pliny's stated views in this respect were not exceptional. To take one of Leach's proposed examples, a novice poet whose blushes proved his "real" (private) modesty, we see that Pliny says not once, but twice $(5.17 .1,4)$, that the youth has met the standards of his ancestors, and so (§4) he will then form part of the standard for his descendants. 20 Pliny's final hope is (5.17.6): mireque cupio ne nobiles nostri nihil in domibus suis pulchrum nisi imagines habeant, "I have a wondrous desire for the nobles of our age to have something fine in their homes besides the imagines." The imagines, the masks of the ancestors, are the concrete symbol of existimatio by the ultimate collective audience--Roman tradition (Habinek MS.27-28; [End Page 83]Polybius 6.52-54). The youth's "private" self is subjected to public scrutiny in an utterly conventional way. Pliny does attach significance to the private, domestic self, but not in a way that indicates any local fluctuation in historical context. 
What, then, about the "cultivation of the self" proper? One manifestation of this phenomenon is the pervasive use of regimens and tests to control the self: dietetics, regularly scheduled self-interrogations, self-imposed denials and temptations (Foucault 1986.50-64). Both Stoic and, to a lesser extent, Epicurean practice follow this mode. ${ }^{21} \mathrm{~A}$ less frequently discussed example is Pliny's teacher Quintilian. The first and most important thing to note about Quintilian's work is described by its title: the Institutio Oratoria is focused not on the $t^{\circ} \times n h$ of speaking (as Aristotle'sRhetoric, the Rhetorica ad Herennium, or Cicero's de Inuentione) or even on the final character of the orator (as Cicero's de Oratore). Rather, it is concerned with the formation of the orator. $\underline{22}$ It provides a graded set of exercises (both written and spoken), discusses physical aspects of creating an orator (1.3.14-18, 10.25-26, 11.15-19), and even gives the occasional rule of thumb for self-testing (e.g., 10.1.112: ille se profecisse sciat cui Cicero ualde placebit, "You will know you have made a good start if you find Cicero very pleasing"). Nor does this shaping end completely when the young orator leaves the rhetor's school. Quintilian's detailed reading list (10.1.46-131) is intended for the benefit of those whose schooling is over (10.1.4), and he recommends that the orator return for renewed formal education after he has had some actual experience (12.6.6-7). $\underline{23}$ It is true that Quintilian takes pains to explain that the aspiring orator can learn during his youth the many things expected of him (12.11.9-30), but this is largely a question of learning the facts and precepts. The exercise of these [End Page 84] precepts is a matter of continual effort (12.1.31): Quare, iuuentus, immo omnis aetas . . totis mentibus huc tendamus, in haec elaboremus: forsan et consummare contingat, "Wherefore in youth, nay every age ... we strive in this direction, we work towards this: perhaps it will even be possible to achieve it." $\underline{24}$ This continual striving is only to be expected since the station of the perfect orator, like that of the Stoic sapiens, is so lofty that it has yet to be attained (12.1.14-20). We should also recall here that the goal of Quintilian's teaching is the uir bonus. These exercises are not just extensive (i.e., spread over time and method), but also intensive (they affect his whole character). $\underline{25}$ Thus Quintilian's program in rhetoric begins to exemplify the same cultivation of the self Foucault located in scientific and philosophical discourses.

Does Pliny exemplify either the intensity or the targeting of this new cultivation of the self? We can certainly find traces. Of his time in a Laurentine villa, Pliny says (4.6.2): ipsum me studiis excolo, "I cultivate myself in my studies." In this letter and in 1.9.4-7 he describes his regimen of reading, writing, exercise, and self-reflection (1.9.5: mecum tantum et cum libellis loquor, "I speak only with myself and my books"). The object of this effort is the cultivation of mind and body in harmony (1.9.4): aut lego aliquid aut scribo aut etiam corpori uaco, cuius fulturis animus sustinetur, "I read or write or even make time for my body, on which the mind is supported." This sense of uacatio is precisely that which Foucault (1986.46) 
notes in Seneca, and the self-reflexivity and mind/body harmony bear a striking resemblance to his Stoic teachings (SenecaEM 106, de Ira 3.13.12). [End Page 85] But, as we have said, 4.6 sets this exercise in a rural villa, $\underline{26}$ and the whole point of $1.9 .1-3,8$ is that these practices are in fact only possible in such a setting. 27 This spatial localization is part of a general pattern in Pliny: use of a formal regimen is consistently connected with some category (here, the rural) which is marginalized in Roman thought. Spurinna is praised for his daily regimen (3.1.4-9), as is Pomponius Bassus (4.23.1). But both are senes (3.1.10, 4.23.2). Pliny himself, however, cannot yet take up this regimen (3.1.11): Hanc ego uitam uoto et cogitatione praesumo, ingressurus auidissime, ut primum ratio aetatis receptui canere permiserit. Interim mille laboribus conteror ...., "I take up this life in my hopes and imagination, and I am eager to enter it for real as soon as my age permits me to take a retreat. In the meantime, I am worn down by a thousand labors ..." In the later letter, Pliny is more specific (4.23.3): Nam et prima uitae tempora et media patriae, extrema nobis impertire debemus, "For we owe both the first and middle portions of our lives to our country, the last to ourselves." Another person praised for his regimen and self-restraint is Artemidorus (3.11.6), who appears to be an alien. $\underline{28}$ The reason that these regimens are connected to the marginal term of each significant opposition (urban/rural, adult/old, Roman/alien) has already been suggested by some of the above quotations: they are, for Pliny, in conflict with [End Page 86] the officia that structure the life expected of an adult male citizen. $\underline{29}$ This is made most explicit in a passage in which Pliny explains why he cannot match his famous uncle's literary production (3.5.19): Ego autem tantum, quem partim publica partim amicorum officia distringunt? "But can I do so much, whom duties to friends and fatherland distract?"

Even given this marginalization of formal regimens, one could reasonably imagine recourse to less systematic practices that would still produce a lifestyle grounded in one's relationship to oneself (Leach 1990.20, 32-33). Again, there are traces of these phenomena in Pliny; at 9.3.3 he tells his correspondent that he worries daily about the criteria by which he should measure his own actions (haec . . . quae cotidie mecum, "These things which I ponder daily with myself"). $\underline{30}$ And Pliny locates his (and his friends') obligation to erect Verginius Rufus' epitaph in a debt to themselves (6.10.5): ipsi nobis debeamus etiam conditoria exstruere, "We owe it to ourselves to erect the tomb as well." $\underline{\underline{11}}$ But, as with the use of formal regimens, a broadly self-directed mode of life is given only marginal status in Pliny's letters.

In fact, Pliny seems to devote less energy to controlling himself and more to controlling what others think about him. For instance, in letter 2.5 Pliny expresses anxiety over circulating a speech. Normally, he says, this would subject his diligentia and fides to popular existimatio, but in this case his pietas is also being judged (2.5.3). Not only his skill and effort are 
subject to public evaluation, but also his motivation. Later, he expresses a desire that posterity maintain positive contemporary judgments of his poetry whether they are right or wrong (7.4.10): qui siue iudicant siue errant, me delectant. Vnum precor: ut posteri quoque aut errent similiter aut iudicent, "They please me whether they judge correctly or err. I pray only one thing: that posterity either err or judge similarly." $\underline{32}$ The most striking thing about this strategy, however, is that Pliny announces it [End Page 87] publicly. Apparently he can legitimately take the position that community approval is sufficient in itself, regardless of the character of the underlying actions that are notionally being judged.

The extreme examples of this community-oriented mode of life are cases where Pliny does not adjust his own life-style in general to suit individual others, but attempts to shape the popular estimation of third parties to make himself look good by comparison. In two letters recommending candidates for election, Pliny expresses anxiety over the consequences for himself should his candidate lose $(2.9 .1,6.6 .9)$. As he says in the former passage: mea existimatio, mea dignitas in discrimen adducitur, "It is my standing and my worth which are brought into question." The election of these recommendees, insofar as it bears on Pliny at all, is a test of his reputation completely divorced from how that reputation came to be. Furthermore, Pliny demands his friends' support on these very grounds (2.9.5-6, 6.6.8); he is not merely interested in the election as a test of standing, he wants to influence it as a way of constructing that standing.

We also have a pair of slightly different examples of a similar strategy of praising. In 4.17.3, Pliny considers aiding the consul-designate in a legal matter in order to increase the prestige of an office he himself once held (the consulship). Eventually, he decides to take the other side to improve his personal reputation for loyalty to friends (4.17.10), but this is not a rejection of the principle of the first strategy; it has merely been superseded by the particulars of this case. Similarly, at 6.17.4, Pliny gives the rule that one should praise authors whose talent is less than or equal to one's own. Why? Quia pertinet ad tuam gloriam quam maxime uideri quem praecidis uel exaequas, "Because it is relevant to your own glory that he whom you surpass or equal seem as great as possible." Again the strategy is to artificially inflate the reputation of others to whom one stands in some fixed relation. Pliny attempts to adjust his standing within the community without regard for any concrete standard of behavior. Incidentally, we may note here that Pliny expects the same kinds of rules of judgment to apply in what we might distinguish as moral and literary spheres. This seems to be a general principle for Pliny, but it is particularly important for his oratory, which could readily be judged in either sphere in any case (cf. above on 2.5.3 and 5.3).

In both of the electioneering examples, the possible defense of the exconsul, and the praise of lesser authors, we see again that Pliny does not 
merely take steps to improve his reputation, but also openly advertises that [End Page 88] fact. Moreover, as with the letter in which he expressed hope that posterity would retain a positive judgment of his poetry (even if it is in some sense "wrong"), this concern with reputation is divorced from indications that the underlying actions or motivations have any inherent value. Pliny displays no anxieties over this approach in which the object of moral evaluation is neither a physical nor a mental self, but a set of social facts. This is a good example of a personne-theory. Examples like these also suggest a way to read other passages in which Pliny interests himself in the politics of reputation. He is not being shallow; he is merely operating in a world in which the most legitimate measure of his worth is whether he fills an appropriate place in the order of the community. $\underline{33}$ In this connection, we should recall that it is not only the construction of Pliny's own reputation which is the subject of his concern. We have also seen that Pliny prefers to evaluate (or claim to evaluate) not from his personal point of view, but as a representative of a collective social judgment $(2.7 .6,4.16 .1,5.11 .2,5.14 .6$, 6.9.2, 10.1.2, 10.86b.1; 2.6.3-4).

In general, Pliny's moral judgments do not depend on the confrontation of individual moral agents with themselves or with some universal, "natural" standard, but on the role of the individual as a representative of one or more social categories. $\underline{34}$ One might include here Pliny's comments on the role of senes (3.1.4, 12; 4.23.3 quoted above), though it could be objected that the reduced responsibilities of the senex are an individual (if predictable) response to the reduction of one's physical capacities through old age. $\frac{35}{5}$ Clearer is the importance Pliny accords to membership in the [End Page 89] senate. $\frac{36}{6} \mathrm{He}$ begins letter 2.11 with the words solet esse gaudio tibi, si quid acti est in senatu dignum ordine illo, "You always rejoice if anything is done in the senate worthy of that order." Dignum ordine illo suggests that senators qua senators are subject to standards different from merely exercising general or individual faculties in the taking of senatorial decisions. In the following letter, Pliny argues that a senator would be more harshly (durior tristiorque) punished by being excluded from a pro-magistracy than by being removed from the senate entirely (2.12.23). 37 The accused's interests as a member of the senatorial class are assumed to be more important (to himself and to others) than his individual interests. Finally, we should recall the passage (5.3.6) in which Pliny implies that greater sanctitas is expected of senators than poets. In a related way, letter 4.17 treats consulars as an ethical class. In a somewhat different vein, Pliny sometimes uses geographical origin as a means of praise $(1.14 .4,6$; 2.13.4). Moral judgment is made not on the individual, but on the class. $\underline{38}$

Contrast this to contemporary trends in philosophy. What all of the exercise and testing is directed at is the unique individual agent; rather than seeing each person as an example of a class or occupation or other ephemeral category, the goal is the improvement of his (or, more rarely, her) 
natural self. This results in appeals to general notions of humanity, rationality, or virtue depending on one's precise notion of "natural." This is the explicit goal of Stoicism: the improvement of the rational governing faculty (3/4gemonikÒn) and its control over impulses and perceptions in accordance with nature. $\underline{39}$ The individual may have to fulfil the role of an ofPce or exercise responsibility with respect to, e.g., kin or fellow citizens, but these actions are not conceived of as specific to the relevant office/descent/citizenship, but as the exercise of more general faculties in response to the particular situation in which one finds oneself (Foucault 1986.88-92). Similarly, Epicureanism urges a renouncement of worldly[End Page 90] things to ensure that one does not depend on anything outside himself for happiness. $\underline{40}$

We can see that Quintilian begins to bring these standards too into the sphere of rhetoric. Again, the key is his interpretation of the uir bonusdefinition of the perfect orator. ${ }^{41}$ To the extent that he is male (uir), he conforms to conventional, strongly-gendered expectations. Quintilian also suggests that he will be a Roman (12.2.7). However, given Quintilian's respect for Demosthenes (e.g., 10.1.105-06, 12.1.14), the latter restriction may be more an acknowledgment of political reality than a claim about national identity. At least in principle, Quintilian's potential audience is quite general. 42 Furthermore, the virtues which bring success to the "good" man are not specific to oratory. Rather, they are quite general characteristics which could find their exercise in virtually any activity: the uir malus is ipso facto foolish and therefore will be an inferior pleader (12.1.4); only the uir bonus has a clear enough conscience to argue well (12.1.4-7); only he can attend properly to the labors that are involved in the orator's self-fashioning (12.1.8); virtuous action is itself one of the key topics of oratory and is best discussed by someone who practices it $(12.1 .8,12.2 .15-17)$; the virtuous man will never want for words because he can simply speak the honest truth (12.1.29-30). Quintilian, of course, asserts the need for technical learning (12.2.1), but it is largely through the exercise of generalizable personal virtue that one fulfils the functions of the orator. [End Page 91]

So far, I have been concerned primarily with more-or-less explicit theories expressed in Pliny's letters. It will also be useful to say a few words about the practice of letter writing itself. For Seneca, the writing of the Epistulae Morales could itself constitute part of the cultivation of the self. It provided an opportunity both for review of past actions (in light of which necessary corrections could be made) and for anticipation of the future (both to make rational decisions and to prepare oneself to bear their consequences appropriately). There seems to be no trace of any of these functions in most of Pliny's letters. What is notable is the care taken in preparing the letters that were destined for publication (paulo accuratius scripsissem, 1.1.1). $\stackrel{43}{\text { In }}$ fact, anxiety over just what to publish is something of a topos for Pliny (cf. $1.8,2.19,3.5,5.12)$. And in 2.10 he goes to some length to tell Octavius 
how important it is that the latter release his works to the public. The writing of the letters (or other works) is not sufficient in itself, as it might be for Stoic self-development; it is their publication that gives them their primary value. Thus Pliny's practice of writing and publishing his letters reflects the same community-oriented ethic that those very letters describe.

Foucault and Leach are right to say that there is no necessary contradiction between, on the one hand, a society in which the individual has strong obligations to the community or in which most actions are subject to public inspection and, on the other, one in which ethical rules are conceived of in terms of one's proper relation to oneself. It is even possible that a society which places a high value on community evaluation could use this standard as part of a "turn to the self." This is particularly true in a case where (as at Rome) tradition (mos maiorum) or collective opinion (e.g., consensus bonorum) were often figured as consistent and unchanging. Thus either (or both) could serve the same kind of role as right reason in Stoic thought or the will of God in early Christianity: the guide according to which the self is shaped. But Pliny does not cultivate his character so much as his standing. It is not clear that, on his own account, he even has a character distinct from his public standing. This is true in two important senses. First, he does not try to shape himself into a person who will characteristically perform right actions (however they may be defined), but [End Page 92] each action is submitted ad hoc for the approval of the community. To use a modern economic metaphor, we may think of the individual as the producer of his own actions. Pliny invests his efforts solely in individual products, while Seneca and Quintilian claim to invest heavily in the means of production. Hence Pliny proposes little anticipatory study or emulation of Cicero (or anyone else) in the letters, as opposed to after-thefact use of him as a self-justificatory rhetorical figure. 44 Second, popular opinion is valued not as a check or standard by which one judges one's progress, which might nonetheless be taken to exist independently, but as an end unto itself. $\underline{45}$ This is shown most clearly by Pliny's willingness to improve his reputation by distorting the mechanisms of praise and blame.

Also, Pliny accepts an identity based on rank (senator, consularis), profession (orator), and (in other cases) origin, rather than on a more individualized sense of self. The exposure of his "private" life, meaningful as a response to the late first-century crisis of representation, should not be mistaken for a cultivation of, or increased sense of, responsibility, to some kind of burgeoning modern "inner self." $\underline{46}$ Pliny was perhaps something of a reactionary even in his own time, committed (in practice, if not in theory) to a series of external judgments and categories. In a way, Cicero, a figure from the now distant republican past, really is a peculiarly appropriate symbol for Pliny's mode of self-fashioning. 
But what about those few passages where Pliny does seem to allot value to some sort of moi (e.g., 1.9.4, 5.3.2, 6.10.5). Are these simply fragments of Zeitgeist which have "rubbed off" on Pliny? Perhaps, but I would suggest that the situation is a little more complicated than that. Pliny is engaging in a deliberate display. The new technologies of the self require, in practice if not always by their own description, considerable time and resources to acquire. The theory presumes a philosophical, if not actually a Greek, education. The practices themselves require, as Pliny suggests, an investment of leisure time. Pliny is displaying an aristocratic indulgence, much as he might display a work of art. [End Page 93]

There is, I think, an illustrative parallel to this kind of display in contemporary American society. The anthropologist George Marcus has made a study of "eccentricity" as a characteristic of possessors of great hereditary wealth in this country (largely third to fifth generation descendants of nineteenth-century industrialists). They share with Roman aristocrats inherited wealth and status and the lack of a profession by which they might define themselves. $\frac{47}{}$ In this study Marcus remarks (1995.49):

[E]ccentricity . . . becomes associated by a larger public with a certain aggressive superiority that the rich and powerful as eccentrics are able to impose and that stands for a presumed entitlement to bend the environments over which they have control toward indulging their nonconformist excesses. The eccentric rich, thus, have the capacity to normalize the institutions and personnel they control in line with what others judge as their peculiarities.

Among other things, these eccentrics show "inversions of common sense habits, gender identifications, and dress" (Marcus 1995.50). It may seem counter-intuitive to compare Pliny, who has rightly been described as the consummate conformist, to these eccentrics. The paradox, however, lies in the norms to which Pliny was conforming. Roman aristocratic culture was highly competitive and involved its members in a constant search for distinction. The double sense of "distinction" is important here--distinction as prestige requires distinction as difference, at least within limits.

American society places considerable value on a moi, in the form of the "personality," under any circumstances. In such a context effective display requires a dramatically different personality. Hence, the eccentric's characteristic inversions of ordinary behavior. In the Roman context, individuality is not ordinarily a virtue. Hence, more subtle calibration of the moi will be salient. Those small investments in a moi can pay dividends for a Roman aristocrat; larger investments may not be proportionally more profitable and may even be counter-productive. Aristocrats allowed themselves [End Page 94] such indulgences, while the ethical canons to which they subscribed required that they restrain them. Or rather, the display value of the indulgences is at some point overmatched by the display value of certain virtues, such as moderatio and devotion to officia. Displays of self-fashioning thus earn two kinds of profit. In themselves, they 
are a classic example of conspicuous consumption. Properly calculated, they also set the more traditional virtues in higher relief by showing how easily the aristocrat can meet his societal obligations. Pliny performs the required restraint by marginalization (as described above) and by the simple fact of recording them in his letters. In a precisely parallel fashion, Cicero displays cultural capital like his knowledge of Greek language and art in his letters in a way unthinkable in the more egalitarian context of a speech. $\underline{48}$ For a Seneca, cultivation of the unique individual self was claimed to be a way of life; for Pliny it was decoration on an individual already constituted as an element of a larger community.

University of Texas at Austin

\section{Notes}

1. I would like to thank Matt Roller, Steve White, Victoria Wohl, and Arethusa's excellent anonymous readers for their comments on earlier drafts of this paper. None of them should be held responsible for any deficiencies, theoretical or empirical, which remain.

2. Riggsby 1995.133 .

3. Roller MS gives a detailed analysis of the argument of this letter in light of Pliny's other comments on poetic composition.

4. Pliny's ethical criticism of delatores does not imply that his targets have failed qua orators in his eyes, pace Picone 1977.155. For a contrasting contemporary view, see Winterbottom 1964 on Quintilian and the delatores. Quintilian makes it clear that the moral qualities are necessary not just to be a good orator (as he understands the notion), but to be an orator at all: Neque enim tantum id dico, eum qui sit orator uirum bonum esse oportere, sed ne futurum quidem oratorem nisi uirum bonum, "For I claim not only this, that a person who happens to be an orator ought to be a good man, but that he will not even be an orator unless he is a good man" (12.1.3, cf. 1.pr.9), orator, id est uir bonus,"an orator, i.e., a good man" (2.17.3).

$\underline{5}$. Nothing militates against the common identification with P. Clodius Thrasea Paetus (cos. suff. 56), more clearly implied at 3.16.10.

6. Seneca (EM 102.12-13) rejects the apparently common view that true gloria requires the consensum multorum (for which view cf. Cic. TD 3.3, Phil. 1.29). Rather, for Seneca, truth can be arrived at rationally and so does not require ratification. Later in this paper we will see other conflicts between Seneca's inner-directed Stoicism and a more traditional Roman collectivism. For Cicero, gloria is granted oligarchically, not democratically (Earl 1967.30 and citations above), but for the present purposes this still makes him a representative of (apparently) received tradition.

7. Picone 1977.151-53 traces this view in Pliny and notes that he may be even more conservative in some respects than his model Cicero. Picone takes the differences in stance (between Cicero and Pliny) to be symptomatic of a more general difference in attitudes towards "theory." I suggest that the causality (if any) may flow in the other 
direction. The public aspects of the role of the orator are not, of course, completely neglected by Quintilian (e.g., 12.1.26, 7.2).

8. Carrithers deliberately and, I think, rightly retains Mauss' French terms to avoid the distracting baggage that any roughly equivalent English words would bring.

9. An obvious problem case for this typology would be the Stoic persona theory of Cic. Off. 1.107-25. I would claim that, as we have it, this theory brings together apersonnetheory and a moi-theory while doing little or nothing to reconcile or even relate them; cf. DeLacy 1977.163-65, 170-72. Gill 1988 examines Cicero's presentation (especially the examples) and argues persuasively that for Cicero and Panaetius "it begins to look as though, in practice, the advice to maintain the universal human persona (and to maintain one's own specific persona) [i.e., the moi aspect] may amount to little more than . . . sharing the competitive ethos of Greco-Roman society" [i.e., the personneaspect] (p. 185). Conversely, Epictetus' handling of similar material tends to collapse all prÖsvpa into a moi defined by universal rationality (Gill 1988.188-90).

10. Earl 1967.20-26, 33-36, Minyard 1985.7-12, and Habinek MS. Cf. CIL I'.15.5-6 (epitaph of Cn. Cornelius Scipio Hispanus, praet. 139): Maiorum optenui laudem, ut sibei me esse creatum / Laetentur; CIL I2.2274 (L. Sulpicius): Ille probatis iudicieis multeis cognatis atque propinqueis; and the epitaph of Atilius Calatinus (Cic. Sen. 61). The fact that these inscriptions also mention external, evaluating audiences confirms the role of the audience in the inscription quoted below in constructing, not merely noting, virtue. See also Feldherr 1991 on the interpretation of spectacle in Livy.

11. $R$ [omai Sirmond, $R$ [omane Grotefend. In more classical Latin: Hunc unum plurimi consentiunt Romae / Bonorum optimum fuisse uirum . . . / Hic cepit Corsicam Aleriamque urbem. / Dedit Tempestatibus aedem merito. I have omitted a list of offices held a[pud vos] in lines 3-4 (the reconstruction is guaranteed by comparison with his father's epitaph). On the elogia of the Scipios see Van Sickle 1987 including bibliography on both the texts and archeological context.

12. Leach 1990.29 n36 offers as an example of separation of public and private Cic. Clu. 138-42, in which Cicero claims the right as an advocate to offer different interpretations of history (in this case the iudicium lunianum) in different speeches. From this it is inferred that, at least in an oratorical situation, one's inner self is not held responsible for one's public actions. However, even leaving aside the embarrassing context of Cicero's theoretical claim, we can cite two facts of oratorical practice that belie it. First, in this very passage Cicero also cites M. Antonius' refusal to publish his speeches lest he be so caught out (Clu. 140); the audience would not allow the separation that Cicero appears to call for. Second, as May 1988.7-10 points out, one of the major differences between Greek and Roman forensic oratory is the deep interdependence in the latter of ethos with the extrinsic facts of social life (i.e., the auctoritas and dignitas generated in other practices, discursive and otherwise). Rhetorical arguments from character (ingenium, natura, persona) might in principle make better evidence for a public/private distinction, but in fact this kind of character is so closely equated with the set of a person's (public) deeds as to make this argument very difficult.

13. Cf. Dionysius 4.24.8, 19.16.5; specific examples are recorded at, e.g., Gellius NA 1.6, 4.20; Suet. Aug. 89; Dionysius 2.25.

14. On invective topoi see Nisbet 1961.192-97. 
15. An example of a slightly different kind of collective judgment, though not one delivered from a broadly significant social position, is found at 2.6.3-4 where Pliny does not merely criticize a host's hospitality on his own authority, but reports a conversation he had with another guest to the same effect.

16. Cf. 4.14.4: erit eruditionis tuae cogitare summos illos et grauissimos uiros qui talia scripserunt non modo lasciuia rerum, sed ne uerbis quidem nudis abstinuisse.

17. The same connection is perhaps implied by the organization into a single chapter of "auctoritas und exemplum" by Bütler 1970, especially pp. 91-92.

18. Earlier in the letter Pliny had also used the metaphor of the consilium, the informal collective judging body at the familial level (and now also the emperor's "cabinet"):quasi ex consilii sententia (§8).

19. On the role of the amicus in Senecan Stoicism see Foucault 1986.52-54. The topic will be considered much more extensively in Livia Tenzer's forthcoming Stanford dissertation.

20. On these chains of copies becoming exemplars see Riggsby 1995.132n18.

21. Epicureans: Epicurus Ep. Men. 129-31, Porphyry Abst. 1.51.6-52.1. Stoics:

Seneca EM 16.2-3, 20.3-4. This paper is not primarily a study of Roman use of Hellenistic philosophy; the references here and in the following notes should be taken as exemplary rather than exhaustive.

22. On the title and its implications see Kennedy 1969.31, 143.

23. This apparently applies to many of the readings and exercises described in book 10 such as the writing recommended on Cicero's authority (10.3.1), or Demosthenes' practice in isolation (10.3.25) or at the seashore (10.3.30), or the translation exercises practiced by a variety of authorities (10.5.1-3). Quintilian mentions iuuenes several times throughout the book, but the exemplars are all adults, as the chapter opening suggests. Another example is the constant exercise of memory needed not only to establish, but to maintain that faculty (11.2.41).

24. Cf. 12.11.16-17: Discendi ratio talis ut non multos <poscat $>$ annos . . Reliqua est <exercitatio>, quae vires cito facit, cum fecit tuetur. Rerum cognitio cotidie crecscit,"Such is the nature of the learning that it does not demand many years ... The rest is exercise which swiftly lends strength and guards it once established. The understanding of affairs grows daily."

25. IO 12.2.1 makes it explicit that the disciplina of the orator is directed at shaping moral character as well as imparting technical knowledge: Mores ante omnia oratori studiis erunt excolendi . . . "Above all, the orator must tend to his character in his studies ..." Roller 1992 shows that a technique of oratorical inventio advocated by Pliny is also at work in other types of composition. This type of "cognitive seepage" shows that even formally rhetorical exercises can shape the orator in more general ways. Note also Quintilian's extensive discussion of gesture (11.3.65-144) which requires the orator's constant monitoring and control over his physical self (on which see Gleason 1990.395, 403).

26. Exercise of the self is also set in the country at 5.6.46, 7.9, 7.10, 9.40; in an urban setting (where the difficulties are pointed out): 7.30.4. The extent to which the villas of the 
rich were all, in fact, places of leisured retreat may be questioned (D'Arms 1981.78-87), but that is certainly their symbolic value in most of Roman literature, as quite clearly in this letter (though contrast 9.15).

27. Cicero employs a more extreme strategy of marginalization in de Re Publica. He sets the dialogue nearer the city, but in horti outside the pomerium (Rep. 1.14; Zetzel 1995.111). The text also frequently reminds the reader that a holiday (the feriae Latinae) provided the opportunity for the recorded discussion (Rep. 1.14.1, 14.2, 20.1, 33.3). Finally, the discussion is justified at length on the grounds that it is more practical and Roman than theoretical and Greek (Rep. 1.33-37). This triple justification indicates that Cicero is working with a conception of aristocratic duty which is even more hostile to intellectual work than the one with which Pliny attempts to compromise. Other Ciceronian dialogues are also set during holidays (ND 1.15, de Or. 1.24), or more general periods of otium (Fin.

1.14, ND 2.3, Leg. 1.13), and/or in rural villas (Div. 1.8, Fin. 1.14, Acad. 1.1, 2.9, de Or. 1.24, Leg. 1.1).

28. Pliny met Artemidorus in Syria (3.11.5); this and his name suggest that he was not a Roman. Sherwin-White 1966.244 points out that Pliny's habit was to give naturalized citizens their full names. That Artemidorus was son-in-law of C. Musonius Rufus $(\S \S 5,7)$ might be taken to argue to the contrary.

29. Bütler 1970.51-55 notes this age difference and usefully compares 7.3 where Pliny criticizes a friend (Praesens) who seems to have retired too early. Foucault 1986.51 records the deferral until old age of the aggressive "possession of the self" in several authors (including Pliny), but makes nothing of it.

30. On the other hand, the two criteria proposed (§§1-2) depend on reputation.

31. The specific principle seems to be roughly "do unto others as you would have them do unto you."

32. Cf. 7.17.8-9 where Pliny says he is more nervous over a large audience than over a single person quamlibet doctus.

33. In a similar vein, Gill 1988.194 shows that in Cicero's discussion of decorum in Off. there is a tendency to teach avoidance of showing one's uitia, rather than the correction of those uitia.

34. Bütler 1970.66-70 discusses the importance of "Rollenkonformismus" to Pliny's ethics. His discussion is useful, but he is too ready to attribute the full sophistication of Ciceronian/Panaetian persona-theory to Pliny. In nearly all his examples, the role is a public, collective one (e.g., lavolenus Priscus in 6.15.3 is a jurisconsult and participant inconsilia, Severus in 6.27 is a consul designate). The question in most of these cases is not the choice between the demands of conflicting personae, but the duties incumbent on the occupier of a single role in a variety of circumstances, a lower-level question. It is this difference of circumstance which provides the facultatem noua, magna, uera censendi (6.27.5), rather than a more complex question of individual roles. The latter is perhaps only clearly illustrated in 1.23 .

35. This individualizing interpretation would require that we take Pliny's comments about the three stages of life (4.23.3) fairly loosely. 
36. Bütler 1970.69 is good on this point; on the other end of the spectrum, 8.16.2 grudgingly recognizes the "virtual" community (res publica quaedam et quasi ciuitas) of slaves.

37. Pliny preferred the imposition of the other sentence (2.12.4), but the reasoning about the strictness of the one imposed is presented as his own.

38. Contrast Quintilian for whom the same virtues make someone a good speaker, a good counselor, a good citizen, and a good man (12.11.1): His dicendi uirtutibus usus orator in iudiciis consiliis contionibus senatu, in omni denique officio boni ciuis, Pnem quoque dignum et optimo uiro et opere sanctissimo faciet.

39. Long 1986.173-209; Diogenes 7.89, Plutarch Virt. Mor. 440e-41d, Seneca EM 124.13-14.

40. Long 1986.66-67, 69-71; Epicurus Ep. Men. 130, SV 58, 81; Seneca EM 9.3.

41. A referee raises the interesting question of the relationship between Cato's uir bonus and Quintilian's, given my claim that Quintilian represents an innovative view of personhood while Cato is presumably more traditional. I see two possibilities here. (1) The uir bonus definition is quite epigrammatic and therefore readily subject to different interpretations. For Cato, bonus may have presupposed more about the class and status of a subject than it seems to have for Quintilian. Compare Cicero's use of boni to refer to a small political group. (2) While Cato was used (by himself as well as later authors) as a figure of traditional virtue, we should not forget that he was, in fact, a novus homo. Defining the orator as a (potentially self-made) uir bonus, rather than as the incumbent of a certain social position would have been very much to his advantage. I incline towards the second possibility.

42. The leisure and formal education required to produce the orator also seem to assume a fair degree of wealth, but this is never made explicit. In fact, the detailed rhetorics of the first century might seem designed as a way of redefining the Roman elite to take in a variety of new families from new areas (Bloomer 1992.12-13, 259). In this respect Quintilian's $1 O$ represents a leveling force.

43. This is true whether the letters were heavily revised for publication or, as Shelton 1987.137n48 and Bell 1989.462, 464-65 plausibly suggest, most letters in Pliny's circle were written in polished literary style to begin with.

44. Exceptions are, perhaps, passages which depict others' attempts to influence Pliny towards certain courses of action by use of the Ciceronian model. Yet this preemptive selffashioning is possible only if it is preceded by a preemptive external evaluation.

45. Contrast the physiognomic texts analyzed by Gleason 1990. Personal appearance and grooming are not merely signifiers of character, but, through a kind of sympatheia, can sometimes affect it (pp. 400-01, 402-03).

\section{Bartsch 1994.214-15.}

47. There are, of course, significant differences as well. Most significantly here, American eccentrics are often reacting against their own perceptions that other aspects of 
their selves, e.g., financial and legal personae, are not under their own control but under that of lawyers, accountants, and other experts (Marcus 1995.43-44).

48. Art: cf. the coy posturing of Verr. 2.4 to Fam. 5.12. Language (and literature): see Steele 1900 and Boyance 1956.116-20, 124-28. In particular, contrast the free citation of Greek literature in a letter like Fam. 13.15 to the exclusive use of Latin in even an already literary speech like pro Caelio. For the class-based restriction of learning see Brunt 1988.302. Habinek 1994 traces Cicero's program of reinforcing Roman aristocratic authority with Greek cultural capital.

\section{Bibliography}

Bartsch, Shadi. 1994. Actors in the Audience: Theatricality and Doublespeak from Nero to Hadrian. Cambridge. 66.

Bell, Albert. 1989. "A Note on Revision and Authenticity in Pliny's Letters," AJP 110.460-

Bloomer, W. Martin. 1992. Valerius Maximus and the Rhetoric of the New Nobility. Chapel Hill.

Boyance, Pierre. 1956. "La connaissance du grec à Rome," RÉL 34.111-31.

Brunt, Peter. 1988. The Fall of the Roman Republic and Related Essays. Oxford.

Bütler, Hans-Peter. 1970. Die geistige Welt des jüngern Plinius: Studien zur Thematike seiner Briefe (Bibliothek der Klassischen Altertumswissenschaften NF, 2R, Band 38). Heidelberg.

Carrithers, Michael. 1985. "An Alternative Social History of the Self," in M. Carrithers, S. Collins, and S. Lukes, eds., The Category of the Person: Anthropology, Philosophy, History. Cambridge. 234-56

D'Arms, John. 1981. Commerce and Social Standing in Ancient Rome. Cambridge.

DeLacy, Philip. 1977. "The Four Stoic Personae," ICS 2.163-72.

Earl, Donald. 1967. The Moral and Political Tradition of Rome. Ithaca.

Feldherr, Andrew. 1991. Spectacle and Society in Livy's History. diss. UC Berkeley.

Foucault, Michel. 1986. The Care of the Self (The History of Sexuality, volume 3) (trans. R. Hurley). New York.

Gamberini, Federico. 1983. Stylistic Theory and Practice in the Younger Pliny. Hildesheim.

Gill, Christopher. 1988. "Personhood and Personality: The Four-Personae Theory in Cicero, de Officiis I," Oxford Studies in Ancient Philosophy 6.169-99. 
Gleason, Maud. 1990. "The Semiotics of Gender: Physiognomy and Self-Fashioning in the Second Century c.e.," in David Halperin et al., eds., Before Sexuality. Princeton. 389415.

Habinek, Thomas. 1994. "Ideology for an Empire in the Prefaces to Cicero's Dialogues," Ramus 23.55-67.

-----. MS. "Why Was Latin Literature Invented?" in T. Habinek, The Politics of Latin Literature (forthcoming).

Kennedy, George. 1969. Quintilian. New York.

Leach, Eleanor. 1990. "The Politics of Self-Presentation: Pliny's Letters and Roman Portrait Sculpture," CA 9.14-39 and unpaginated plates following.

Long, Anthony. 1986. Hellenistic Philosophy: Stoics, Epicureans, Sceptics². London.

Marcus, George. 1995. "On Eccentricity," in Debbora Battaglia, ed., Rhetorics of SelfMaking. Berkeley. 43-58.

May, James. 1988. Trials of Character: The Eloquence of Ciceronian Ethos. Chapel Hill.

Minyard, Douglas. 1985. Lucretius and the Late Republic (Mnemosyne Supplement 90). Leiden.

Nisbet, Robin (ed.) 1961. Cicero: in L. Calpurnium Pisonem Oratio. Oxford.

Picone, Giusto. 1977. L'eloquenza di Plinio: Teoria e prassi. Palermo.

Riggsby, Andrew. 1995. "Pliny on Cicero and Oratory: Self-Fashioning in the Public Eye," AJP 116.123-35.

Roller, Matthew. 1992. "Plinian Reminiscences of Catullus and Literary Inventio," AAPA 124.47.

-----. MS. "The Politics of Literary Appropriation." 39.

Shelton, Jo-Ann. 1987. "Pliny's Letter 3.11: Rhetoric and Autobiography," C\&M 38.121-

Sherwin-White, Adrian. 1966. The Letters of Pliny. Oxford.

Steele, R. B. 1900. "On the Greek in Cicero's Epistles," TAPA 31.xvi-xvii.

Van Sickle, John. 1987. "The Elogia of the Cornelii Scipiones and the Origin of the Epigram at Rome," AJP 108.41-55.

Winterbottom, Michael. 1964. "Quintilian and the Vir Bonus," JRS 54.90-97.

Zetzel, James (ed.) 1995. Cicero: de Re Publica, Selections. Cambridge. 